\title{
上腕骨近位端骨折に対する手術治療経験
}

\author{
山口赤十字病院整形外科 \\ 小川光・佐々木 邦 雄 \\ 大 宮 克 弘・宮 本 敬 士 \\ 河野修
}

\section{Operative Treatment of Proximal Humeral Fracture}

\author{
Hikaru Ogawa, Kunio Sasaki, Katsuhiro Omiya, \\ Keishi Miyamoto and Osamu Kawano \\ Department of Orthopaedic Surgery, \\ Yamaguchi Red Cross Hospital
}

Most proximal humeral fractures could be treated by conservative treatment, and only a few patients were treated by operation. In this study, we discuss 20 patients, 14 with 2-part and 6 with 3-part fracture. The JOA score was 82.0 point, and major complications were seen in one patient.

Key words : Proximal humeral fracture (上腕骨近位端骨折), Surgical treatment (手術的 治療)

$$
\text { はじめに }
$$

上腕骨近位端骨折は，大部分が Minimal displacementであり，また有効な保存的治療も多く手 術的治療を必要とする症例は少ない，今回，当科にお いて手術的治療を施行した上腕骨近位端骨折症例のう ち，特に高齢者を中心に検討を行なった．

\section{症例}

1992 年 1 月より 1998 年 12 月までの期間に, 当科 において手術的治療を施行した症例のうち，6 カ月以 上経過観察可能であった 20 症例， 20 骨折（うち 60 歳以上の症例は 16 例）を対象とした。性別は男 8 例, 女 12 例, 年齢は 13 歳から 94 歳, 平均 68 歳であった。 骨折型は, Neer の分類で 2 part 骨折 14 例, 3 part 骨折 6 例で，4 part骨折はなかった。また臨床評価 は，直接診察を行ないJOA スコアにて判定した。

手術法は T-plate 固定 6 例, Hook plate 固定 1 例, Kirschner wire（以下 K-wire と略す）及び wire, screw による固定 7 例, J 型 K-wire の逆行 性刺入による固定 3 例 $^{3)}$, K-wire による固定 1 例, Resection arthroplasty 2 例であった.

\section{結果}

Resection arthroplasty 2 例を除く, 18 例中 16 例にレントゲン上骨癒合が得られた（表 1)。レント ゲン上骨癒合が得られなかった 2 症例は，K-wire 及 び wire で固定した症例と, J 型 K-wire の逆行性刺 入による固定を行なった症例であり, 共に 80 歳以上

表 1

\begin{tabular}{c|c|c}
\hline \hline & $\mathrm{X}-\mathrm{P}$ (骨瘉合) & JOA score \\
\hline K-wire, wire, screw & $6 / 7$ & 68.3 \\
T-plate & $6 / 6$ & 98.0 \\
Hook plate & $1 / 1$ & 99.0 \\
J-K-wire & $2 / 3$ & 76.0 \\
K-wire & $1 / 1$ & 100.0 \\
\hline 計 & $16 / 18$ & 82.0 \\
\hline
\end{tabular}


と高齢で，高度の骨粗琭症を合併していた。

JOA スコアは，K-wire 及びwireで固定した者が 平均 68.3 点, $\mathrm{J}$ 型 $\mathrm{K}$-wireによる固定を行なった者 が平均 76.0 点で, そのほかの術式の平均は 98.0 点以 上, 全ての平均は 82.0 点であった.

年齒別に見ると, 60 歳未満の症例の JOA スコアは, 全て Excellentで, ADLの障害はほとんどなかった. これに刘し，60歳以上の症例の JOA スコアの平均は, 78.0 点と比較的良好であったが，その中には Fair 以 下の症例を 3 例認めた。

合併症としては，2 例が偽関節となりそのうちの 1
例は骨頭壊死を生じた。Plateの逸脱を認めた症例は, 経過中に立分な骨癒合が得られた。初期 RSD を 1 例 に認めたがすぐに改善をみた。尺骨神経領域のしびれ， Wireによる Impingement や K-wire の backed outには抜釷を行なった。

\section{症 例 呈 示}

症例 163 歳, 男性, 2 part 骨折, 入院後 10 日間 ゼロポジション毫引をするも整復できず, T-plateに よる骨接合術を行なった（図 1). 最終診察時, レン トゲン上良好な骨癒合が得られ変形もなく, JOA ス
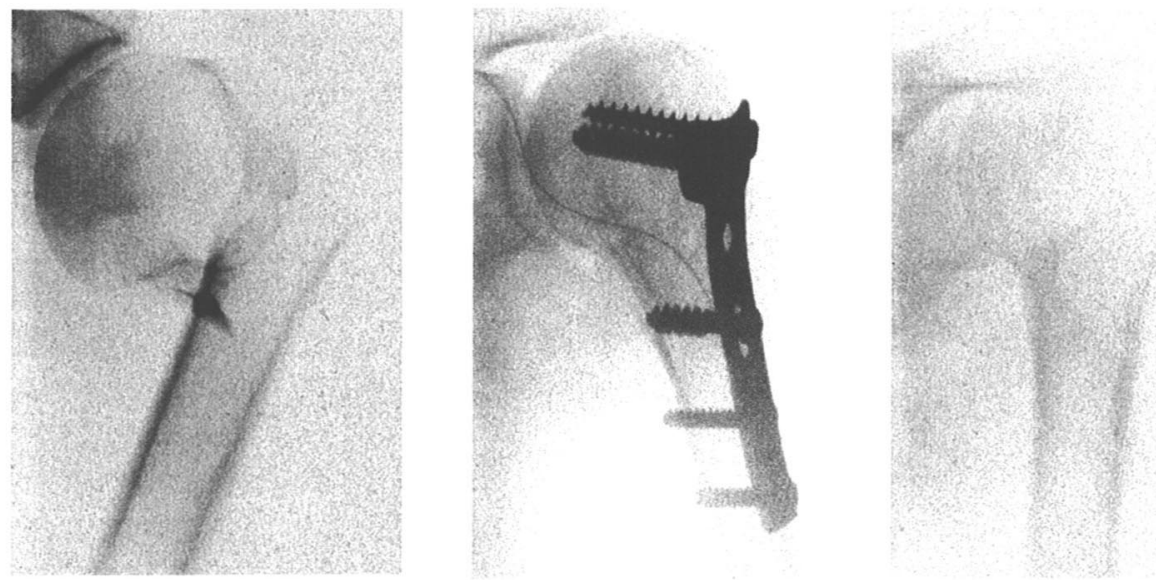

図 163 藏, 男性

T plateによる骨接合施行し，良好な骨癒合を得た。
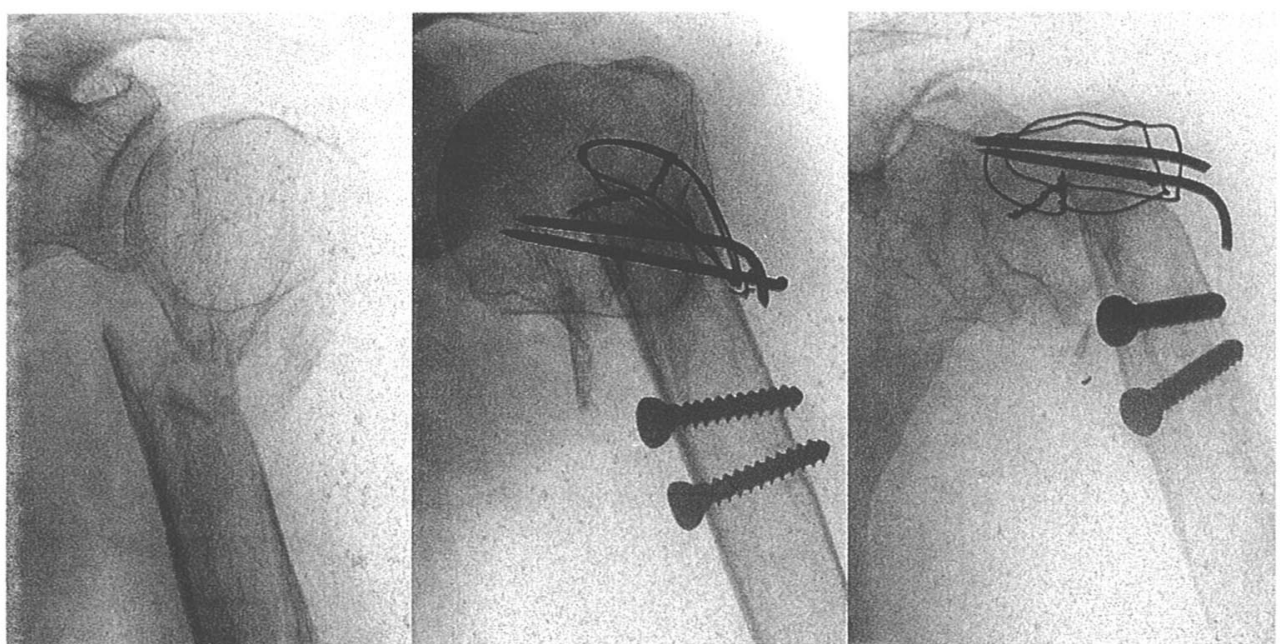

図 280 歳, 女性

K-wire, wire, screwによる固定を行うも偽関節となり，最終的には骨頭は吸収されていた. 
コアは 100 点であった。

症例 280 歳, 女性, 2 part 骨折, 痴呆のため, ゼロポジション牵引が出来なかった症例である（図 2). K-wire 及びWire · Screw による骨接合術を施行し たが，術後痴呆の進行による不穏状態が続き，骨頭の 亜脱臼・偽関節を生じた。術後全身状態が悪化したた め再手術はできず，最終診察時には，骨頭は壊死・吸 収され，K-wire が関節内に突出していた。痴呆のた め, 痛みの訴えはあまりないが, JOA スコアは 30 点 と Poorであった

\section{考}

察

上腕骨近位端骨折は，大部分が Minimal displacementであり，また転位を生じていても，牽引 や体幹固定などの保存的治療で治癒するものが多い. しかし, 近年高齢化に伴い, 手術的治療を必要とする 上腕骨近位端骨折も堌加傾向にあり，特に高齢女性で 骨粗妝症が高度な症例の手術を行なう機会に遭遇する ことが多くなった。このような症例では，骨粗鬆症が 基盤にあるために，内固定の loosening などにより 骨癒合が得られにくく，また変形癒合による可動域制 限のため, 高度の ADL 障害を生じる症例も少なくな い.今回我々が報告した症例の中にも，骨粗鬆症に起 因する合併症を生じ，高度の ADL 障害を生じた症例 があり，反省すべき点と思われる7．高齢者の上腕骨 近位端骨折の治療はまず保存的治療を行なうことを基 本とし, 手術を行なうさいも心肺機能低下などの全身 合併症, 術後の肺炎・痴呆の併発などを考慮にいれる ことは言うまでもないが，術式は侵襲の少ない，早期 に可動域訓練を開始できるものを選択すべきである.
例えば, 今回 3 例に施行した, 2 part 骨折に対する J 型 K-wire の逆行性刺入法は, 伝達麻酔下でも手術が 可能であり非常に有効な方法と思われる。

$$
\text { ま と め }
$$

上腕骨近位端骨折の手術的治療例の検討を行なった. 20 例中 18 例に骨癒合が得られ JOA スコアの平均も 82.0 点と比較的良好な成績が得られたが, 合併症の ため高度の ADL 障害を生じた症例も認めた。治療は 可能な限り保存的治療が望ましいが, 手術的治療を行 なうときは慎重な術式の選択が必要である.

\section{参 考 文 献}

1）遠藤寿男：上腕骨近位端骨折の保存的療法. 整・災外, $30: 357-364,1987$.

2) Jaberg, H.: Percutaneous stabilization of Joint Surg. 74-A : 508-515, 1992.

3）宮沢知修ほか：上腕骨近位端骨折に対する Kirschner 鋼線檤内固定法による治療。整・災外，38：1339-1345, 1995.

4) Neer, C. S. II : Displaced proximal humeral fractures. Part I. Classification and evaluation. J Bone Joint Surg., 52 : 1077-1089, 1970.

5) Neer, C.S. II : Displaced proximal humeral fractures. Part II. Treatment of three-part and four-part displacement. J Bone Joint Surg., 52-A : 1090-1103, 1970 .

6）野村茂治ほか：上腕骨近位端骨折の観血的治療の適応 と問題点. 整. 災外, $30: 365-379,1987$.

7）岡村圭佑ほか：上腕骨近位端の骨粗辈症と骨折。関節 外科, $13: 641-646,1994$.

8) Sidor, M. L.: The Neer classification system for proximal humeral fractures. intraobserver reproducibility. J Bone Joint Surg., 75-A : 1745-1750, 1993. 